more contracted the bladder, the more rigid the bladder, the more pronounced the autonomic distension syndromes which they had described.

The answer to the question of abortion he thought was now quite clear. From all the experience they had at Stoke Mandeville there was no indication as far as the paraplegia as such was concerned to do an abortion.

Araluze, F. (Spain), thought it would be very interesting to follow up the growth of the children born in these cases. Mainly because there was a possibility of minimal severe brain damage which was not easily detected within the first months but very easily detected in later life. He wondered if anyone had done so to see if there were any such brain damage or not.

Guttmann, L., said he could answer this. The children were absolutely normal in every aspect. The boy of the patient previously mentioned, with a high lesion and the suprapubic cystotomy, who had been pretty ill before with pressure sores, was Io years old. He went to school with normal children and came with his mother every year to the Games. The same applied to all other children who had been borne by the Centre's paraplegic women.

\title{
ELECTRO-MYOGRAPHIC STUDY OF THE FLEXION REFLEX OF THE LOWER LIMB
}

\author{
By G. M. Pool \\ Zuider Ziekenhuis, Rotterdam
}

INTRODUCTION

NoRMAL walking is an action, which, for the most part is involuntary and brought about by reflexes which are co-ordinated by a computer. The voluntary part of the action occurs through stimuli in motor fibres of a certain thickness in which there is a certain conduction velocity.

In view of this conduction velocity this system of fibres is called the alpha motor system. The conduction in this system is not continuous, but only present when a movement or working of a muscle or musclegroup is wanted.

Besides the alpha system we know the gamma system, which regulates the tone of the muscles. In this system there is a more or less constant inflow of stimuli from cerebral centres along thinner fibres with a lower conduction velocity (gamma). These stimuli are reflected via the muscle spindle. The gamma system could be compared with a radar: in the cerebral centre a tone image is formed from the reflected gamma stimuli and the centre becomes aware of the state of mobility of the muscles.

The regulation of tone in the muscle is monosynaptic and based on the stretch reflex. The p.t.r. is an example of this, passive stretching of the muscle elicits an increase in tone.

In the case of patients with a paraplegia normal walking is not possible because of a disturbance in the stimulus conduction whereby the computer can no longer, or not so well, regulate the reflexes and also the gamma radar system is more or less interrupted. 
A very important reflex for a walking person is the polysynaptic flexion reflex of the lower limb, which in case of a paraplegia is overactive and often disturbed by the monosynaptic stretch reflex. Kenney and Haeberlin (1962) made a comparative electro-myographic study with an eight-channel penwriting machine and skin electrodes in I4 normal children and I 3 with cerebral palsy of comparable ages. They found a characteristic pattern of the spastic child while performing several different actions and suggested that this pattern may be due to agonists acting against the 'built-in' resistance offered by the antagonists when activated by the stretch reflex. The pattern of the normal child acting against external resistance was comparable with that of a spastic child moving without that resistance.

Thomas (I96I) has given a survey on the present views on muscle tone and spasticity and points out how passive extension of the muscle results in a reflex contraction that tends to resist the extension. The increased resistance by passive movement of an extremity is in this way explained in so called spastic conditions.

Kugelberg (1948) made an electro-myographic study with various stimuli and found that the flexion reflex really consists of two parts, namely an $\mathrm{A}$ and a $\mathrm{C}$ section, according to the conduction speed in the afferent $\mathrm{A}$ and $\mathrm{C}$ fibres. $\mathrm{He}$ controlled a reflex discharge on stroking the sole of the foot with a needle with varying force on heat stimulation at different temperatures and with an electric stimulation of different intensities. Kugelberg inserted the needles through an intracutaneous wheal of procaine, in order to diminish pain and stated that the pain may sometimes be sufficiently intense to elicit or maintain a reflex. Kugelberg et al. (1960) also made a study of the muscles involved in the withdrawal response of the flexion reflex and found that in contrast to the vastus musculature the rectus femoris muscle is involved, serving as a flexor of the hip. Marshall (I954) states that the flexor reflex is best elicited by a noxious stimulus applied to the skin or deep tissues of the foot, but the receptive field may extend over the whole of the lower limb even on to the anterior abdominal wall.

\section{CLINICAL MATERIAL}

The flexion reflex was studied in 18 patients with a paraplegia. The paraplegia varied in severity from those with only slight weakness to those with complete motor and sensory paralysis.

\section{METHODS}

Electrical stimuli were applied to the tissues under the skin of the sole of the foot, while the patient was in recumbent position.

A Disa stimulator provided square wave pulses of 10 to $30 \mathrm{~m} . \mathrm{sec}$. duration. The maximal strength of the pulse was 50 volts. The leg was left free to move. No local anaesthetic was given to reduce pain reaction. Each patient was examined several times with an interval of one to three months. The stimulation was applied by two needles inserted a few millimetres apart. The retlex responses were recovered bipolar from two needle electrodes inserted 10 and $12 \mathrm{~cm}$. above the patella into the $\mathrm{m}$. rect. femoris. 


\section{RESULTS}

The reflex responses were of three different types:

I. A response pattern of different lengths, after which no further action potentials were seen or heard and which did not seem to differ from the pattern recovered from a control person. This type we found in twelve patients (fig. I).

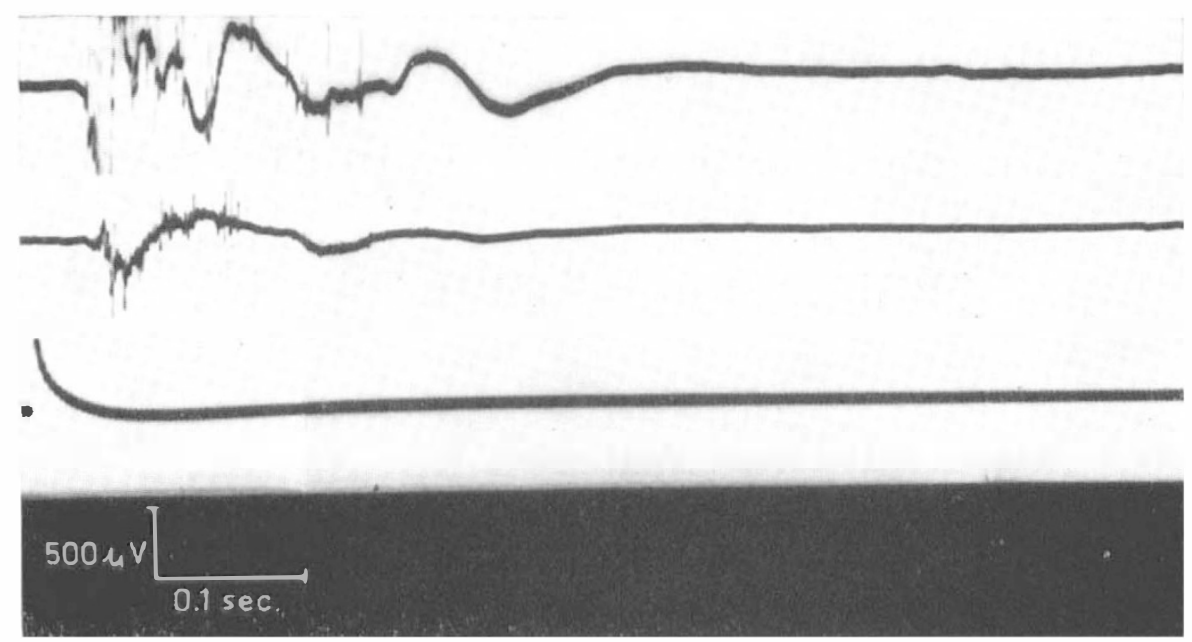

FIG. I

2. A response pattern, which appeared to be continuous, this type being found in two patients in all examinations (fig. 2).

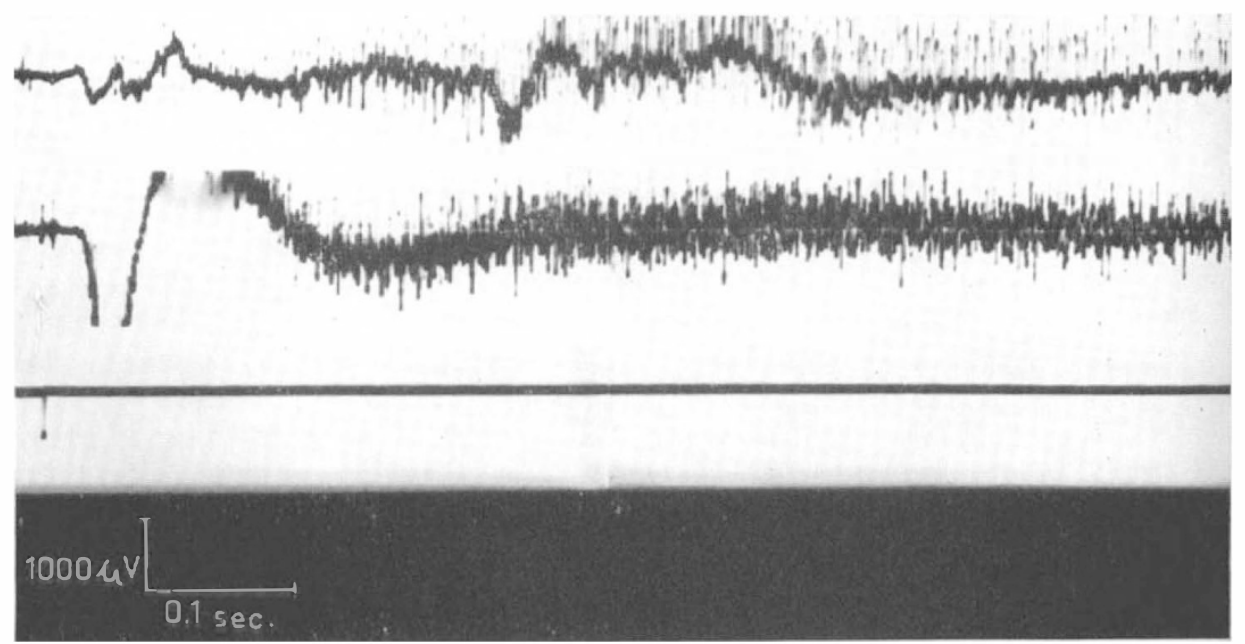

FIG. 2 
3. A response pattern of short duration, followed by a rest period of varying lengths, after which a new burst of action potentials followed. This last type was found in two patients having a complete cervical lesion (fig. 3 ).

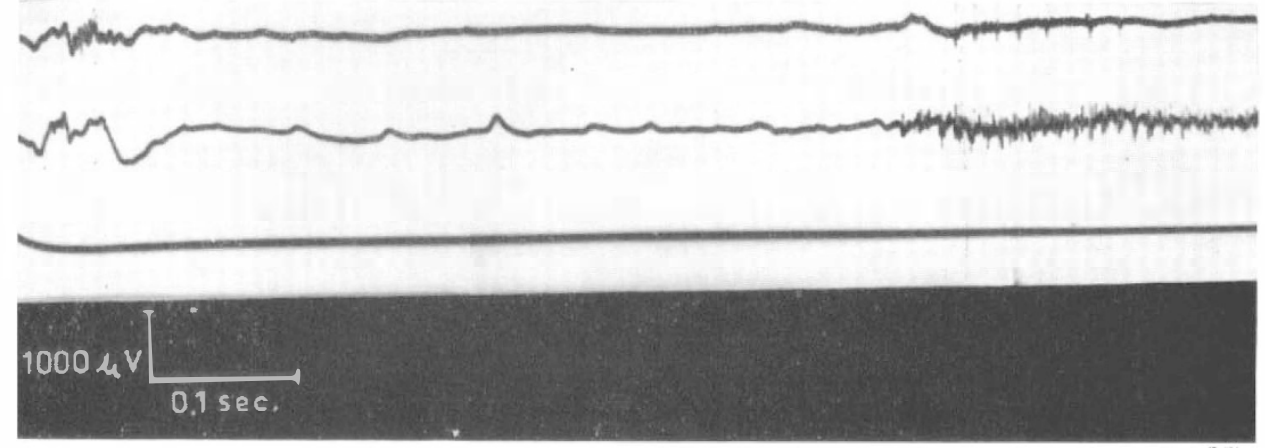

FIG. 3

\section{ANALYSIS OF RECORDS}

The reflex patterns obtained are very difficult to analyse, because of the complex of stimuli which are normally present apart from the electrical ones. Also in all examinations the recordings taken from 10 and $I 2 \mathrm{~cm}$. above the patella were different. They only were in fair agreement regarding the duration of the reflex response and so we divided the patterns in the three types mentioned above. Apart from the electrical stimulus the insertion of the needles itself is a nociceptive stimulus too. The painful stimulus might be responsible for the continuous action in the second type as Kugelberg suggested. Probably the myogram of this type consists of a combination of the flexion reflex and the stretch reflex, evoked by the continuous stimulus of the needles. It may be possible that the resistance offered by the stretch reflex neutralises the action of withdrawing the leg into flexion from the pain induced by the needles. The rest period in the third type was not of a constant length, but depended on the time in which the leg returned to the rest position. If the leg was prevented from returning to that position, the second burst did not occur. The burst was only seen when the leg was allowed to return freely and is probably evoked by the stretch reflex. The $\mathrm{m}$. rectus femoris being passively stretched by gravity, the muscle being without any active tone control, and the stretch reflex in the cases of a complete lesion being only of spinal origin.

\section{SUMMARY}

The flexion reflex of the lower limb was studied in I 8 patients with paraplegia. The paraplegia varied in severity from those with slight weakness to those with complete motor and sensory paralysis.

Electrical stimuli were applied to the deep tissues of the sole of the foot, while the patient was in recumbent position. The leg was left free to move.

No local anaesthetic was given to reduce pain reactions

The reflex responses were of three different types: 
I. A response pattern of different lengths, after which no further action potentials were seen or heard.

2. A response pattern, which appeared to be continuous.

3. A response pattern of short duration, followed by a rest period, after which a new burst of action potentials.

The significance of the reflex activity is discussed.

\section{RÉSUMÉ}

Le réflexe en flexion du membre inférieur a été étudié chez I 8 paraplégiques. Ceux-ci présentèrent des formes variables allant de la forme parétique légère à celle de l'atteinte motrice et sensorielle complète.

Les stimuli électriques furent appliqués aux tissus profonds de la plante du pied, le malade étant en décubitus dorsal, la jambe était libre. Aucune anesthésie locale ne fut administrée pour la douleur. On distingue trois types de réponses :

(I) Un type de réponse d'amplitudes différentes après quoi plus d'action de potentiel audible ou visible.

(2) Une réponse de type continu.

(3) Une réponse de durée courte, suivie d'une période de repos, elle-même suivie d'une nouvelle salve de potentiels d'action.

La signification de l'activité réflexe est discutée.

\section{ZUSAMMENFASSUNG}

Der Beugereflex der unteren Extremität wurde an I8 Paraplegikern untersucht. Der Grad der Querschnittsschädigung wechselte von leichter Parese bis zum kompletten Transversalsyndrom.

Elektrische Reize der Tiefengewebe der Fusssohle wurden verwandt. Der Patient befand sich in Rückenlage, das Bein lag frei für Bewegungen.

Keine Lokalanaesthesie wurde angewandt, um Schmerzreaktionen zu verhindern.

3 verschiedene Reaktionen wurden beobachtet:

(I) ein Reaktionstyp von verschiedener Länge,

(2) eine kontinuierliche Reaktion, die den Reiz überdauerte,

(3) ein Reaktionstyp von kurzer Dauer, gefolgt von einer Ruheperiode, nach welcher erneut Aktionspotentiale auftraten.

Die Bedeutung dieser Reflextätigkeit wird diskutiert.

\section{ACKNOWLEDGMENTS}

This study was carried out in the Dijkzigt Ziekenhuis in Rotterdam. I am indebted to Dr. M. Vlieger for his invaluable assistance.

\section{REFERENCES}

Kenney, W. E. \& Heaberlin, P. C. (I962). F.R.P.T. Clinical Orthopaedics, No. 24.

KugELBERG, E. (I948). Brain, $7 \mathbf{I}$.

Kugelberg, E., EkLund, K. \& Grimby, L. (1960). Brain, 83.

MARShall, J. (1954). Brain, 77.

Thomas, J. E. (I96I). F. Nerv. and Ment. Dis., 132.

\section{Discussion}

Rossier, A., remarked that Dr. Pool had compared the resting period followed by firing units after stimulation of the striated muscles with the stretch reflex of the bladder. He would like to concur with him because he thought they had ample proof from a clinical point of view that it was in fact so. All who were familiar with the treatment of the neurogenic bladder knew that very often when a bladder of the upper motor neurone 
type was insufficiently full even before the patient tried to elicit the reflex arc of the bladder it did not succeed. On the contrary, if he waited long enough in order to elicit stretch reflex until a certain point it would be much easier for him to empty his bladder.

Dr. Pool, adding to the point, said if one looked at this reflex which he thought was also possible in the bladder and one pressed slightly with the hands on the bladder, stretch reflex was evoked earlier and in that way the bladder of a total lesion patient was emptied. Pressure with the hand could evoke stretch reflex.

Guttmann, L., said he would like to draw attention to the importance of Dr. Pool's paper from the management point of view of paraplegics and tetraplegics with spasticity. The question was how far could one encourage the development of the stretch reflex in the legs. There was no doubt about the preponderance of the flexion synergy in the reflex return. This led, if the early management were not done properly, to increased reflex flexion contractions of the legs ending finally in flexion contractures. $\mathrm{He}$ had stressed again and again that in order to promote the extensor reflex, the legs in the acute stages should be kept not in flexion by putting a pillow under the knees but in extension and abduction. This position promoted and encouraged extensor response, thus diminishing the overaction of the hip and knee flexors. One could also use the stretch reflex to restore standing of paraplegic patients by the action of muscles which had their segmental innervation in the spinal cord above the level of the lesion but on the other hand were fixed with their insertion points in the paralysed part of the body, especially the pelvis. The important muscle for this was the latissimus dorsi. If a paraplegic stood in parallel bars he had a tendency to relapse in flexion. This could be overcome quite easily if the patient pulled up his pelvis by the action of his latissimus dorsi and erector spinae. This pull on the pelvis consequently resulted in a pull on the paralysed gluteal muscles and elicited an extensor reflex which promoted standing.

\title{
A NEW TURNING-TILTING BED
}

\author{
By Professor L. Guttmann, C.B.E., M.D., F.R.C.P., F.R.C.S. \\ National Spinal Injuries Centre, Stoke Mandeville Hospital, Aylesbury, England
}

THERE is general agreement that the care and management of paraplegic patients, especially in the early stages following traumatic lesions, places heavy demands on both medical and nursing staff. Pressure sores have to be avoided at all costs, and to achieve this various turning methods have been introduced. The most gentle handling so far was, of course, regular manual turning of the patient by the ward staff, but this requires, in patients with fracture-dislocations of the spine, three or four people to do this. Having regard to the high survival rate of traumatic paraplegics and tetraplegics associated with severe injuries to the chest and other parts of the body on the one hand and the increasing difficulty in all countries to get adequate nursing staff, turning beds have been introduced. The most well known is the Stryker frame and its modifications. However, as I have pointed out repeatedly, this type of turning frame has its disadvantages in the management of fracture dislocations, especially those of the thoracic and lumbar vertebrae. While in such a frame hyperextension by posture with rolls underneath the fracture, necessary to reduce the fracture-dislocation, can be achieved in the supine position, this cannot be maintained by turning the patient in the abdominal position, which is the only alternative in this type of turning bed. Thus the object of maintaining hyperextension to secure re-alignment and promote stability of the broken spine is 